\title{
Petrology and Fluid Inclusion Study of W+Sb \pm Au Quartz Vein Mineralization in Sebuku Island, South Kalimantan, Indonesia
}

\author{
Arvida Noviana $^{1}$, Arifudin Idrus ${ }^{1 *}$, Yoseph Calasanctius Amita Swamidharma ${ }^{2}$, \\ Iwan Setiawan $^{3}$, Chun-Kit Lai ${ }^{4}$ \\ ${ }^{1}$ Department of Geological Engineering, Faculty of Engineering, \\ Universitas Gadjah Mada, Yogyakarta, Indonesia \\ ${ }^{2} \mathrm{PT}$. Sebuku Iron Laterite Ore (SILO), Indonesia \\ ${ }^{3}$ Geotechnology LIPI, Bandung, Indonesia \\ ${ }^{4}$ Faculty of Science, Universiti Brunei Darussalam, Brunei Darussalam \\ *Corresponding author: arifidrus@ugm.ac.id
}

Article received: 4 December 2020, revised: 15 March 2021, accepted: 28 July 2021

DOI: $10.51835 /$ ijeg.2021.1.1.347

\begin{abstract}
Sebuku Island in South Kalimantan province has hosted one of the largest Fe-Ni laterite deposits in Indonesia. Surface mapping has discovered new ore deposit types, notably quartz-bearing $\mathrm{W}+\mathrm{Sb} \pm \mathrm{Au}$ ore veins in the northern Sebuku. This study aims to characterize this newly-discovered deposit type and understand its origin. We present geological mapping, petrographic and ore microscopic observations, and data from XRD, bulk-ore major and trace element (XRF and ICPMS), as well as fluid inclusion microthermometric analyses. The results show that the host rocks are composed of metasandstone and metapelitic rocks. The quartz veins are associated with narrow alteration zones, comprising silicic, sericite and argillic types, which are strongly controlled by NEtrending dextral and SE-trending sinistral strike-slip faults. The veins trend approximately $\mathrm{N} 120^{\circ} \mathrm{E}$, and have massive, brecciated, drusy, comb and bladed textures. Ore minerals comprise mainly wolframite, stibnite, kermesite, tripuhyite, and minor arsenopyrite, pyrite and Fe-Ti oxides. The ores contain up to $958 \mathrm{ppm} \mathrm{W}$ and $1,220 \mathrm{ppm} \mathrm{Sb}$, with wolframite and stibnite being the main ore minerals. Medium homogenization temperatures (Th) were found for the fluid inclusions, ranging from 238 to $>350^{\circ} \mathrm{C}$, which correspond to moderate fluid salinity of 1.4 to 5.4 wt.\% $\mathrm{NaCl}$ eq. Based on those characteristics, the $\mathrm{W}+\mathrm{Sb} \pm \mathrm{Au}$ mineralization in Sebuku is similar to a mesothermal type.
\end{abstract}

Keywords: Indonesia, Sebuku Island, $\mathrm{W}+\mathrm{Sb} \pm \mathrm{Au}$ mineralization, quartz vein-type deposit, fluid inclusion.

\section{INTRODUCTION}

Sebuku Island is part of Meratus Range that located in the south-eastern part of Kalimantan Island. Sebuku Island is one of the places in Kalimantan where the pre-Tertiary basement complex has been exhumed to the surface (van Bemmelen, 1949). Sebuku Island is known as one of Indonesian's largest source of lateritic iron resulted from the weathering process of serpentinite and metasomatism (Exploration Division PT SILO, 2013). Based on the surficial mineralization mapping reported by Exploration Division PT SILO (2017), Sebuku Island hosts numerous deposits, including $\mathrm{W}+\mathrm{Sb} \pm \mathrm{Au}$ quartz veintype deposits.

Studies on the quartz veins on the island are very limited, and the characteristics and origin of the deposit are not fully understood. This preliminary study aims to characterize the host rocks, ore minerals assemblage, and hydrothermal fluids to determine the geological control of the mineralization process, and to determine the deposit type in the study area. Our new data and interpretations could be used to support future exploration activity on the island. 
The study area is located in the Meratus occurs in the Cretaceous between MesoRange where this zone can generally be Tethys and Sunda Shelf caused the divided into three geomorphological zones, magmatism activity (Soesilo et al., 2015). The including (i) mountains, (ii) karst, and (iii) exhumation processes of Meratus Range undulation hills and peneplains (Rustandi et occurred during Miocene (Satyana and al., 1995). The study area displays undulation Silitonga, 1994). The geological structures in hills and peneplains that elongated from north the study area consist of thrust fault, NE-SW to south, the hills occupied at the eastern part trending dextral strike-slip fault and SE-NW and the peneplains at the western part of trending sinistral strike-slip fault.

Sebuku Island.

According to Rustandi et al. (1995), the study area is occupied by ultramafic rock (Mub), Pitap Formation (Ksp), Haruyan Formation (Kvh), diorite (Kdi) and alluvium (Qa). Based on the surface mapping, the study area consists of metamorphosed harzburgite, dunite, serpentinite, gabbros, metasandstone, metapelite, silicified rocks, phyllite, microdiorite and alluvium (Fig. 1).

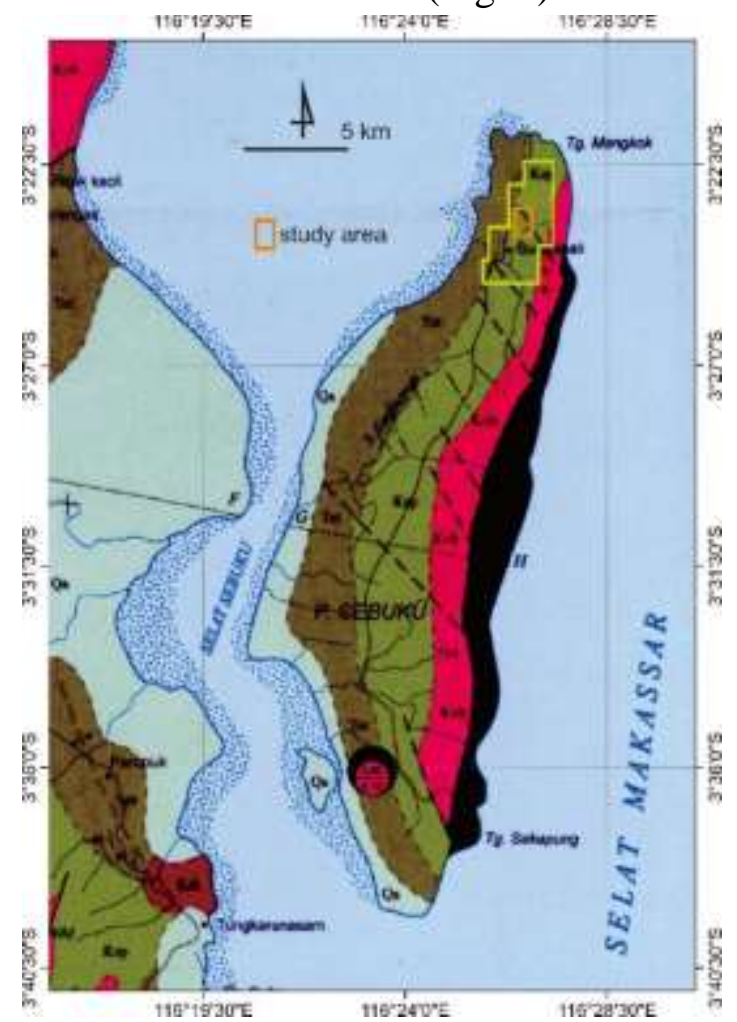

Fig. 1 Regional geology of Sebuku Island (Rustandi et al., 1995) and location of study area.

The geological structure that develop in Sebuku Island are generally controlled by the activity of tectonic plate from Jura (Rustandi et al., 1995). The subduction process that

\section{METHODOLOGY}

The methods of this research divided into fieldwork and laboratory analysis. Fieldwork consists of geological and quartz vein mapping in area $9.8 \mathrm{~km}^{2}$ with scale of 1:10,000. Laboratory works consist of microscopic observation, X-Ray Diffraction (XRD) analysis, whole rock geochemical analysis by means of XRF (X-Ray Fluorescence) and ICP-MS (Inductively Coupled Plasma Mass Spectrometry), and fluid inclusion microthermometric analyses. Microscopic observation of thin section and polished sample was carried out at Optical Geology Laboratory of Department of Geological Engineering UGM. XRD analyses was done at Central Laboratory of Department of Geological Engineering UGM. XRF and ICP-MS analyses were carried out at PT. SILO laboratories. Fluid inclusion microthermometric analysis was performed by using Linkam THMS600 heating and freezing stage at Optical Laboratory of Puslitbang Geoteknologi LIPI Bandung.

\section{RESULTS AND DISCUSSION}

\section{Petrology and Hydrothermal Alteration}

Based on detailed mapping, the study area is occupied by meta-harzburgite, meta-dunite, serpentinite, gabbros, metasandstone, metapelite, silicified rocks, phyllite, microdiorite and alluvium units. 
metasandstone and metapelitic rocks are the host rocks of ore mineralization (Fig. 2). Due to strong alteration and weathering, those rock units are poorly exposed in the study area. The fresh- to least altered metasedimentary rocks show grey color with fine to medium grained fragments, which set in very fine grained matrix textures. The fragments are mainly composed of quartz, mica and opaque minerals. In addition, XRD analysis shows the presence of quartz, mica, chlorite, illite, goethite and pyrite in the metasedimentary rocks. The rocks exhibit massive, layering and phyllitic structure. Based on the mineralogical characteristics, the rock units in study area have been affected by regional metamorphism processes.

The rocks have been suffered by hydrothermal alteration, which is recognized as silicic, sericite and argillic types. Silicification zone is typified by the presence of quartz + cristobalite + trydimite \pm plagioclase. Sericite-alteration zone is characterized by sericite + quartz + pyrite \pm mica \pm illite. Argillic zone shows mineral assemblage of illite + smectite + kaolinite \pm chlorite.

\section{Ore Mineralogy}

Ore mineralization is characterized by SE-NW tungsten and antimony-bearing quartz vein. The vein occurs as open space filling in fault, the orientation approximately $\mathrm{N} 120^{\circ} \mathrm{E}$ dipping $80-90^{\circ}$ and parallel to SE-NW trending regional fault (Fig. 2). The quartz vein characterized by massive, brecciated, vuggy, comb and bladed textures. The quartz vein width is up to $1 \mathrm{~m}$ (Fig. 3).

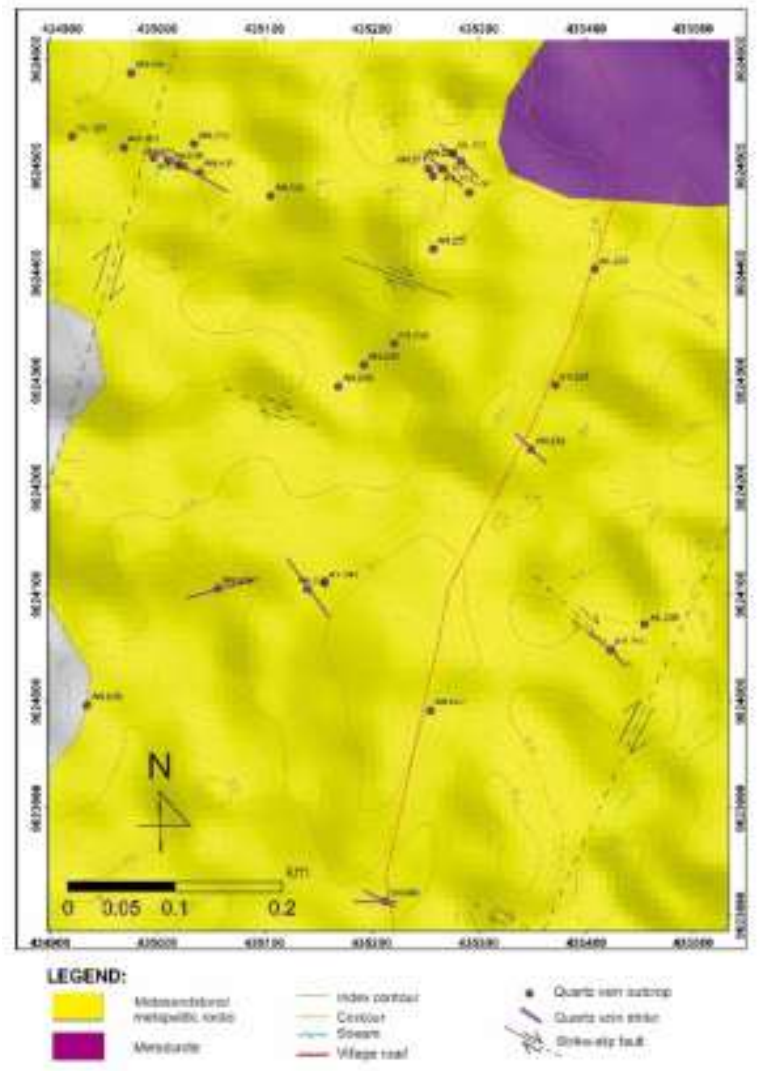

Fig. 2 Local geology with $\mathrm{W}+\mathrm{Sb} \pm \mathrm{Au}$ bearing quartz vein distribution.

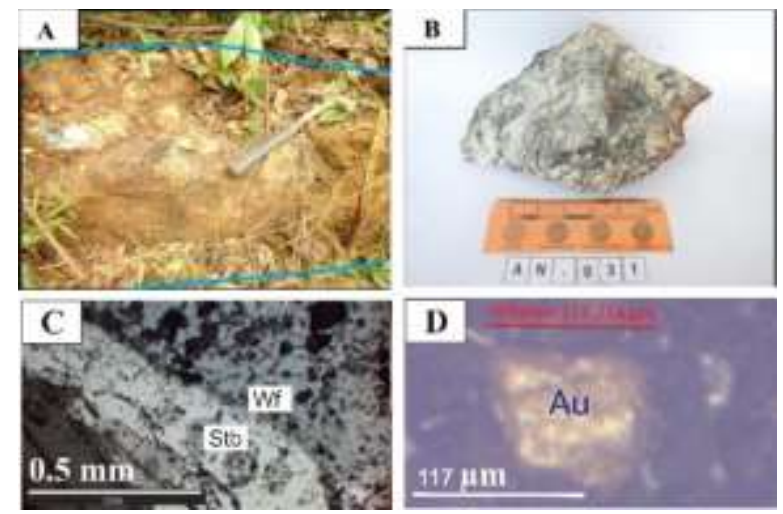

Fig. 3 Ore mineralization: (A) $\mathrm{W}+\mathrm{Sb} \pm \mathrm{Au}$ bearing quartz vein, (B) handspecimen of brecciated quartz vein, (C) microscopic image of wolframite (Wf) and stibnite (Stb), and (D) placer gold grain panned near the vein.

Some of the quartz vein are barren. Ore mineralization mainly composed by wolframite, stibnite, tripuhyite, kermesite, arsenopyrite, pyrite and $\mathrm{Fe}-\mathrm{Ti}$ oxides. Wolframite has light to medium grey color, distinct cleavage and low reflectance. The marginal part of wolframite is replaced by the 
sulfides. Kermesite is an oxide altered from stibnite. This mineralization is grade up to 958 ppm $\mathrm{W}$ and 1,220 ppm Sb with wolframite and stibnite present as its abundant ores. Stibnite might be formed at late stage of mineralization at temperatures of $150-250{ }^{\circ} \mathrm{C}$ (Neiva et al., 2008). Gold is found as isolated grain in quartz by pan concentrate sampling at the creek near the quartz vein. Gold is not recognized in handspecimen or microscope. Gold might be associated with pyrite and arsenopyrite and formed during the first stage of mineralization (Cooper, 1949).

\section{Fluid Inclusion Microthermometry}

Fluid inclusion microthermometry measurements were conducted on fluid inclusion in quartz vein to estimate the temperature of trapping of mineralizing fluid. The inclusion shape is -rounded to rounded and the size range from 5 to $20 \mathrm{um}$. Monophase (liquid or vapor), two-phase (liquid + vapor) and three phase (liquid + vapor + solid) fluid inclusions are observed in quartz vein. The average homogenization temperature of the hydrothermal fluids ranges from $238-295{ }^{\circ} \mathrm{C}$ also $320{ }^{\circ} \mathrm{C}$ until more than $350{ }^{\circ} \mathrm{C}$ and the salinity range from 1.4-5.4 wt.\% $\mathrm{NaCl}$ equivalent. The moderate temperature and salinity of ore fluid are similar to those of mesothermal type (Wilkinson, 2001).

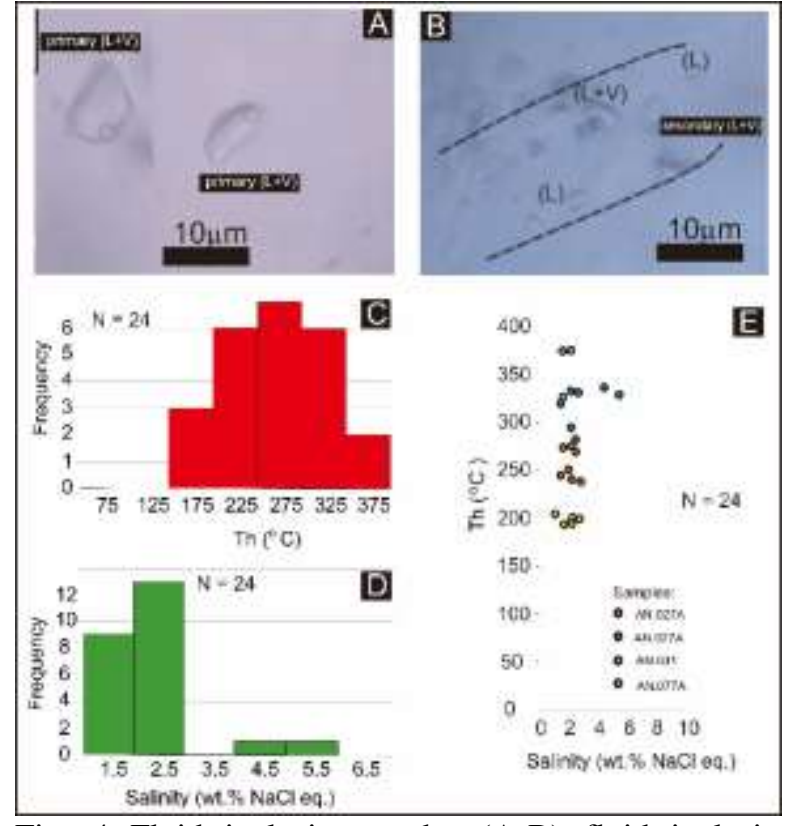

Fig. 4 Fluid inclusion study: (A-B) fluid inclusion petrography, (C) temperature of homogenization (Th), (D) salinity, and (E) plotting Th against salinity.

\section{Discussion}

The $\mathrm{W}+\mathrm{Sb} \pm \mathrm{Au}$ bearing mineralization quartz veins in study area are hosted by metasedimentary rocks. The quartz veins are controlled by SE-NW trending sinistral strikeslip fault. Ore is dominated by massive wolframite, stibnite, arsenopyrite and pyrite. Gold might be present. Supergene process leading oxidation of the sulfide and produce kermesite, tripuhyite and $\mathrm{Fe}-\mathrm{Ti}$ oxide minerals. Tripuhyite has also been observed in Bombana and Buru Island mesothermal gold deposit (Idrus et al., 2011; 2014).

Hydrothermal alteration is characterized by zonal alteration from near the quartz vein consist of silicic, sericite and argillic types. The homogenization temperature and salinity indicate mixing of fluid. Based on fluid inclusion data, host-rocks and ore mineralization, the quartz vein bearing $\mathrm{W}+\mathrm{Sb} \pm \mathrm{Au}$ in study area tends to be similar to a mesothermal deposit type (cf. Groves et al., 1998; Goldfarb et al., 2005). The $\mathrm{W}+\mathrm{Sb} \pm \mathrm{Au}$ bearing quartz vein in the study area shows some similarities with mesothermal gold 
deposits in Canadian Cordillera (Nesbitt et al., 1989). Massive texture of quartz vein is common. Some open space filling textures such as comb and bladed are present, but these are not necessarily indicative of epithermal style. These textures could be occurred in mesothermal deposit type if the hydrothermal fluids forming the ore deposit have the right phase separation condition (personal communication, Richard J. Goldfarb, 2011).

\section{CONCLUSION}

Based on this research, the study area is occupied by meta-harzburgite, meta-dunite, serpentinite, gabbro, metasandstone, metapelite, silicified rocks, phyllite, microdiorite and alluvium. Geological structures in the study area consist of thrust fault, NE-SW trending dextral strike-slip fault and SE-NW trending sinistral strike-slip fault. Lithology that becomes the host rock mineralization are metasandstone and metapelitic rock, meanwhile the geological structure that control the mineralization are SE-NW trending sinistral strike slip fault. Based on the mineralogical characteristics, lithology in the research area affected by regional metamorphism process and hydrothermal alteration.

\section{REFERENCES}

Cooper J.R., 1949, Geology of the Tungsten, Antimony and Gold Deposits Near Stibnite, Idaho: Geological Survey Buletin 969-F, 151-197.

Divisi Eksplorasi PT. SILO, 2013, Laporan Pemetaan Geologi PT. SILO, Kalimantan Selatan. PT Sebuku Iron Lateritic Ores, unpublished, 33p.

Divisi Eksplorasi PT. SILO, 2017, Geologi Sebuku dan Potensi Cebakan Mineral, Joint Convention IAGIHAGI-IATMI-IAFMI: Malang.

Goldfarb, R.J., Baker, T., Dube, B., Groves, D.I, Hart, C.J.R., dan Goselin, P., 2005, Distribution, Character, and Genesis of Gold Deposits in Metamorphic Terranes: Economic Geology 100 Anniversary, 407-450.
Groves, D.I., Goldfarb R.J., Gebre-Mariam, M., Hagemann, S.G., dan Robert, F., 1998, Orogenic Gold Deposits: A Proposed Classification in the Context of Their Crustal Distribution and Relationship to Other Gold Deposit Types. Ore Geology Reviews 13, 7-27.

Idrus, A., Prihatmoko, S., Hartono, H.G., Idrus, F., Erwono, Franklin, Moetamar dan Setiawan, I., 2014, Some Key Features and Possible Origin of the Metamorphic Rock-Hosted Gold Mineralization in Buru Island, Indonesia. Indonesian Journal on Geoscience 1, 9-19.

Idrus, A., Nur, I., Warmada I.W., dan Fadlin, 2011, Metamorphic Rock Hosted Orogenic Gold Deposit Type as a Source of Langkowala Placer Gold, Bombana, Southeast Sulawesi: Jurnal Geologi Indonesia 6, 43-49.

Neiva, A.M.R., Andras, P., Ramos, J.M.F., 2008, Antimony Quartz and Antimony-Gold Quartz Veins from Northern Portugal. Ore Geology Reviews 34, p. 533546.

Nesbitt, B.E., Muehlenbachs, K., Murowchick, J.B., 1989, Genetic Implications of Stable Isotope Characteristics of Mesothermal Au Deposits and Related $\mathrm{Sb}$ and $\mathrm{Hg}$ Deposits in the Canadian Cordillera: Economic Geology 84, 1489-1506.

Rustandi, E., Nila, E.S., Sanyoto, P., dan Margono, U., 1995, Peta Geologi Lembar Kotabaru, Kalimantan Selatan. Pusat Penelitian dan Pengembangan Geologi, Skala 1:250.000.

Satyana, A.H., dan Silitonga, P., 1994, Tectonic Reversal in East Barito Basin, South Kalimantan: Consideration of the Types of Inversion Structures and Petroleum System Significance: Proceedings of the $23^{\text {rd }}$ Indonesian Petroleum Association Annual Convention.

Soesilo, J., Schenk, V., Suparka, E., dan Abdullah, C.I., 2015, The Mesozoic Tectonic Setting of SE Sundaland Based on Metamorphic Evolution. Proceedings of the $39^{\text {th }}$ Indonesian Petroleum Association Annual Convention \& Exhibition.

van Bemmelen, R.W., 1949, The Geology of Indonesia: General Geology of Indonesia and Adjacent Archipelagoes, Vol 1A: Netherlands, The Hague, 732p.

Wilkinson, J.J., 2001. Fluid inclusions in hydrothermal ore deposits, Lithos 55, 229-272. 